University of Nebraska - Lincoln

DigitalCommons@University of Nebraska - Lincoln

\title{
Livestock Management During Drought in the Northern Great Plains. I. A Practical Predictor of Annual Forage Production
}

R. E. Kruse

Montana State University

M. W. Tess

Montana State University

R. K. Heitschmidt

Fort Keogh Livestock and Range Research Laboratory

Follow this and additional works at: https://digitalcommons.unl.edu/usdaarsfacpub

Part of the Agricultural Science Commons

Kruse, R. E.; Tess, M. W.; and Heitschmidt, R. K., "Livestock Management During Drought in the Northern Great Plains. I. A Practical Predictor of Annual Forage Production" (2007). Publications from USDA-ARS / UNL Faculty. 857.

https://digitalcommons.unl.edu/usdaarsfacpub/857

This Article is brought to you for free and open access by the U.S. Department of Agriculture: Agricultural Research Service, Lincoln, Nebraska at DigitalCommons@University of Nebraska - Lincoln. It has been accepted for inclusion in Publications from USDA-ARS / UNL Faculty by an authorized administrator of DigitalCommons@University of Nebraska - Lincoln. 


\title{
$\pi$ \\ Livestock Management During Drought in the Northern Great Plains. I. A Practical Predictor of Annual Forage Production
}

\author{
R. E. Kruse, ${ }^{*}$ M. W. Tess, ${ }^{* 2}$ and R. K. Heitschmidt $\dagger$ \\ *Animal and Range Sciences Department, Montana State University, Bozeman 59717; and USDA- \\ ARS, Fort Keogh Livestock and Range Research Laboratory, Miles City, MT 59301
}

\begin{abstract}
This research addressed the hypothesis that spring precipitation data can be used to detect agricultural drought early in the growing season. The Rangetek range model was used to simulate yearly forage data based on historical precipitation and temperature records from the USDA-ARS Fort Keogh Livestock and Range Research Laboratory (Miles City, MT) and the Agriculture and Agri-Food Canada Manyberries Substation (Lethbridge, AB, Canada). Monthly total precipitation and monthly average maximum and
\end{abstract}

\footnotetext{
${ }^{1}$ Research was conducted under a cooperative agreement between USDA Agriculture Research Service and the Montana Agriculture Experiment Station. Mention of a proprietary product does not constitute a guarantee or warranty of the product by USDA, Montana Agriculture Experiment Station, or the authors and does not imply its approval to the exclusion of other products that may also be suitable. The USDA-ARS Northern Plains Area is an equal opportunity and affirmative action employer and all agency services are available without discrimination.

2Corresponding author: mwtess@ montana.edu
}

minimum temperatures were used to develop regression equations predicting growing season forage production at the Fort Keogh Laboratory and Manyberries Substation. At Fort Keogh Laboratory, a combination of fall (October and November) and spring (April and May) precipitation were predictors of simulated forage yield index $(P<$ $\left.0.01, R^{2}=0.84\right)$. At Manyberries Substation, April and May precipitation were predictors of simulated forage yield index $\left(P<0.01, R^{2}=0.44\right)$. Using the actual forage data from $\mathrm{Ma}$ nyberries Substation yielded similar results, in that April, May, and June were predictors of forage production $(P$ $\left.<0.01, R^{2}=0.50\right)$. Although the regression equation for actual forage production data from Manyberries Substation did indicate that July precipitation was a significant predictor, adding July precipitation did not increase the ability of the equation to detect reduced forage production. These results imply that annual forage production can be estimated with considerable confidence by July 1 and that forage produced by early July is a good indicator of total growing season forage production. Early season detection of drought effects on forage production provides much-needed flexibility in devising management alternatives to minimize the negative impacts of drought on rangelands and beef enterprises.

Key words: forecasting, primary production, simulation, modeling

\section{INTRODUCTION}

Drought is an inherent trait of most rangelands including those found in the Northern Great Plains. For example, Hurtt (1951) reported drought occurred once every $5 \mathrm{yr}$ in southeastern Montana, and Johnson (1985) reported drought occurred once every $4 \mathrm{yr}$ in southeastern Alberta.

The impacts of drought on rangeland ecosystems are numerous and well documented with much of the early ecological research conducted on Great Plains rangelands being driven by the droughts of the 1930s (Weaver and Albertson, 1936, 1939, 1944; Ellison and Woolfolk, 1937; Whitman et al., 1943; Albertson et al., 1957). In general, research has shown that drought conditions reduce both quantity and quality of forage produced and consumed with the resulting effect being a general decline in animal production on both 
an individual animal and per unit area of land basis (Valentine, 1990; Weltzin and McPherson, 2003; Heitschmidt and Vermeire, 2005, 2006).

For livestock managers a fundamental problem with drought is its unpredictability. Hence, livestock management strategies and tactics are often reactive rather than proactive. In this study the effects of drought were confined to effects on forage production. The broad objective of this study was to identify key climatic variables associated with drought in the Northern Great Plains whereby impending effects on forage production could be predicted with considerable confidence. Previous research at this location has shown that on average about $90 \%$ of Northern Great Plains annual graminoid production is completed by early July (Heitschmidt and Vermeire, 2005). As a result, we hypothesized that high-impact variables would most likely be from a fairly short period of time (e.g., spring) rather than an entire frost-free growing season.

Successfully meeting this objective was prerequisite to developing the cow-calf drought management strategies presented in a companion paper (Kruse et al., 2007).

\section{MATERIALS AND METHODS}

Our approach was to develop and evaluate predictors (multiple regression equations) of annual forage yield from 3 different data sets: one simulated based on climatic and soil data from Miles City, MT; one simulated based on climatic and soil data from Lethbridge, $A B$, Canada; and one composed of actual forage and climatic data collected at Lethbridge, AB. Preliminary analyses of several models revealed small local data sets (i.e., limited to a few years and multiple sites in Miles City, MT) were inadequate to satisfactorily address our objectives. Hence, we used a locally validated model of rangeland for- age yield (Rangetek) to simulate long periods of time representing the 2 locations (Miles City and Lethbridge). An existing large data set (Lethbridge, $\mathrm{AB}$ ) was used to evaluate the simulation approach.

Rangetek (Wight and Neff, 1983), a modified version of the Ekalaka Rangeland Hydrology and Yield Model (ERHYM-II; Wight and Hanks, 1981; Wight, 1987) was used to simulate yearly forage yield based on historical precipitation and temperature records from the USDA-ARS Fort Keogh Livestock and Range Research Laboratory near Miles City, MT $\left(46^{\circ} 22^{\prime} \mathrm{N}\right.$ $105^{\circ} 5^{\prime} \mathrm{W}$ ) and from the Agriculture and Agri-Food Canada Manyberries Substation near Lethbridge, $\mathrm{AB}$, Canada $\left(49^{\circ} 7^{\prime} \mathrm{N}, 110^{\circ} 28^{\prime} \mathrm{W}\right)$. The $30 \mathrm{yr}$ of climate data from Fort Keogh Laboratory and $50 \mathrm{yr}$ of data from the Manyberries Substation (Smoliak, 1986) were used to develop regression equations predicting growing season forage production (simulated yield index). The $50 \mathrm{yr}$ of forage production data were also used from the Manyberries Substation (Smoliak, 1986) to develop regression equations predicting actual forage yield.

\section{Rangetek Model}

Rangetek is a climate or waterbalance model, which provides daily simulation of soil water evaporation, transpiration, runoff, and soil water routing for individual range sites. It can utilize real-time climate data to simulate ongoing processes, or it can utilize longterm weather records to simulate runoff and herbage production under a variety of climatic conditions and management practices (Wight, 1987). Driving variables are daily precipitation, minimum and maximum air temperatures, and solar radiation, which can be simulated by the model. Plant variables required by the model include percent graminoids, percent bare ground, leaf area index, date of start of growing season, date of peak standing crop, date of end of growing season, and a relative growth curve. Soil inputs include number of soil layers, texture, thickness, percent OM, percent sand, percent clay, percent rock fragments, bulk density, and initial soil water. Runoff and site variables include longitude, latitude, elevation, slope, and aspect.

Water enters the system as precipitation and may leave the system as runoff, deep drainage, evaporation, or plant transpiration. As water accumulates in the soil, progressively deeper soil layers are filled to field capacity, and excess water drains to the next layer. Water may be lost from the system as runoff or deep drainage if soil profile is saturated. Soil evaporation and plant transpiration, in that order, remove water from the soil profile, beginning with the uppermost layer. Potential evapotranspirative demand is calculated with the Jensen and Haise (1963) evapotranspiration equation. The potential demand is partitioned into potential transpiration and potential evaporation; values are used to calculate actual transpiration and evaporation (Johnson, 1985).

Output from the model is in the form of a yield index. The yield index calculated by the model is an estimate of plant growth for current climatic conditions and site parameters and is expressed as a fraction of site potential yield (Johnson, 1985). This cumulative index equals the ratio of actual transpiration to potential transpiration. The index, or predicted total plant yield, is calculated on the date that peak standing crop occurs. The product of site potential yield $(\mathrm{kg} /$ ha) and the yield index therefore provides an estimate of cumulative production (Johnson, 1985). The yield index is considered a good indicator of the growing season climate as it relates to plant growth and enables comparisons of range treatments or vegetation inventories among years or range sites by 
accounting for a large portion of climate-induced variation in plant response (Wight, 1987).

\section{Fort Keogh Laboratory, Miles City, MT}

Herbage production data were from an unpublished study conducted by the USDA Natural Resource Conservation Service over a 3 -yr period (1991 to 1993) at the Fort Keogh Laboratory. Climate at Miles City is semiarid with annual precipitation averaging $34 \mathrm{~cm}$. Vegetation at Fort Keogh Laboratory is grama-needlegrass-wheatgrass (Bouteloua-Stipa-Agropyron) mixed grass dominant (Kuchler, 1964). Dominate species are western wheatgrass [Pascopyrum smithii Rydb. (Love)], threadleaf sedge (Carex filifolia Nutt.), needle-and-thread [Hesperostipa comata (Trin. \& Rupr.) Barkworth], blue grama [Bouteloua gracilis (H. B. K.), and Japanese brome (Bromus japonicus Thunb. ex Murr.]. The dominant shrub is Wyoming big sagebrush (Artemisia tridentata subsp. wyomingensis Beetle and Young).

Annual production was measured on 12 sites from a single harvest near time of peak standing crop (i.e., mid-July; Table 1). General soil characteristics were found in the Natural Resource Conservation Service survey for Custer County, MT. Initial soil water percentage for all sites was reported by Heitschmidt et al. (1999). Temperature and precipitation data (NOAA, 2001) were from Miles City Airport, located about $10 \mathrm{~km}$ from study sites. Simulated yield index values for the 12 sites were averaged to produce a single predicted index value for statistical analyses.

\section{Manyberries Substation, Lethbridge, $A B$}

Climatic, site, and vegetation data were collected at the Manyberries Substation. Climate at Lethbridge is semiarid with annual precipitation averaging $33 \mathrm{~cm}$. Soils are loamy Aridic Haploborolls and vegetation belongs to the Stipa-Bouteloua faciation of the Mixed Prairie Association (Smoliak, 1986). Principal herbaceous species are needleand-thread, western wheatgrass, blue grama, prairie junegrass (Koeleria cristata (Lam.) Beauv.), Sandberg's bluegrass (Poa sandbergii Vasey), and threadleaf sedge (Smoliak, 1986). The dominant shrub is fringed sagewort (Artemisia frigida Willd.).

The single, end-of-growing season (i.e., late September) harvest data set spanned $53 \mathrm{yr}$ (1930 to 1983). The data set had been used in related study published by Smoliak (1986). Site variables included Wardlow soil series type, north aspect, an elevation of $938 \mathrm{~m}$, and a slope of 3\%. Vegetation variables included an average yield of 388 $\mathrm{kg} / \mathrm{ha}, 79 \%$ gramminoids, 30\% bare ground, and a leaf area index of 0.70 . General soil parameters for the Alberta site were found in the Canadian Soil Series survey.

\section{Statistics}

Summarizing from above, 3 data sets were used: 1) $30 \mathrm{yr}$ of simulated production (i.e., yield index) at Fort Keogh Laboratory; 2) $50 \mathrm{yr}$ of simulated production (i.e., yield index) at Manyberries Substation; and 3) $50 \mathrm{yr}$ of field estimated production (i.e., forage yield) at Manyberries Substation. Our hypothesis was that the effects of emerging drought on forage production could be reliably identified from temperature and precipitation data collected from a subset of the growing season (e.g., before July 1). Simulated data were used because actual forage production data were not available for the area of our primary interest (Montana). The simulation model was developed and validated for this area (Wight and Neff, 1983). For the Alberta location both simulated and actual data were used to provide a type of validation to the use of the simulated data.
Data were collated to correspond to the growing season year to enable a measure of agricultural drought, when moisture during the growing season is inadequate to support healthy forage growth to maturity, prevent extreme forage stress, and permit normal forage production (Kulshreshtha, 1989; Thurow and Taylor, 1999). Based on previous studies at both locations (Smoliak, 1986; Heitschmidt and Vermeire, 2005), the regressed 12-mo growing year was defined as extending from the previous $\mathrm{Au}$ gust through the current July.

Multiple regression methods were used to determine the effects of the climatic factors on range forage production; i.e., simulated yield index at both locations and actual yield at Manyberries Substation. The stepwise multiple regression procedure of SAS (SAS Inst. Inc., Cary, NC) was used to select the most accurate prediction equations. Independent, or predictor, variables used were monthly total precipitation and monthly average maximum temperatures. Variables remained in the model only at an $\alpha$-level of 0.05 . Best predictors were identified, first using all available data (monthly temperature and precipitation). A second set of predictors was identified constraining the predictor variables to months prior to July. Because temperature variables contributed little to the predictive ability of the equations, a third set of equations was developed using only monthly precipitation prior to July.

\section{RESULTS AND DISCUSSION}

\section{Fort Keogh Laboratory, Miles City, MT}

Measured precipitation over the 30 -yr period was quite variable (Table 2). Greatest annual precipitation recorded was $51.5 \mathrm{~cm}$ in 1978 and the least was $13.4 \mathrm{~cm}$ in 1988 . Mean annual precipitation for the area was $35.2 \mathrm{~cm}$. On average, 72\% 
Table 1. Input variables for the Rangetek model from 12 sites at USDA-ARS Fort Keogh Livestock and Range Research Laboratory, Miles City, MT

\begin{tabular}{|c|c|c|c|c|c|c|c|}
\hline Soil series & Range site & Aspect $^{1}$ & Elevation $(\mathrm{m})$ & $\begin{array}{l}\text { Slope } \\
(\%)\end{array}$ & $\begin{array}{c}\text { Average yield }{ }^{2} \\
(\mathrm{~kg} / \mathrm{ha})\end{array}$ & $\begin{array}{c}\text { Grass } \\
(\%)\end{array}$ & $\begin{array}{c}\text { Bare } \\
\text { ground (\%) }\end{array}$ \\
\hline Cabbart & Shallow & NNE & 2,600 & 8 & 1,038 & 75 & 35 \\
\hline Cabbart & Shallow & NNE & 2,640 & 6 & 985 & 75 & 35 \\
\hline Cambeth & Thin silty & ENE & 2,720 & 15 & 997 & 90 & 25 \\
\hline Creed & Claypan & SSE & 2,540 & 1 & 1,442 & 75 & 40 \\
\hline Ethridge & Clayey & $\mathrm{N}$ & 2,642 & 1 & 1,270 & 75 & 20 \\
\hline Kobase & Clayey & ESE & 2,424 & 5 & 1,717 & 70 & 20 \\
\hline Twilight & Thin sandy & $\mathrm{E}$ & 2,560 & 15 & 1,094 & 85 & 27 \\
\hline Twilight & Sandy & SSW & 2,660 & 18 & 1,122 & 85 & 10 \\
\hline Yamacall & Silty & NE & 2,540 & 10 & 1,458 & 85 & 5 \\
\hline Wabek & Shallow to gravel & $\mathrm{N}$ & 2,622 & 1 & 1,001 & 65 & 30 \\
\hline Wabek & Shallow to gravel & NW & 2,570 & 10 & 719 & 65 & 30 \\
\hline Wabek & Shallow to gravel & SE & 2,600 & 18 & 1,362 & 65 & 30 \\
\hline
\end{tabular}

${ }^{1} \mathrm{NNE}=$ North-northeast; $\mathrm{ENE}=$ east-northeast; SSE = south-southeast; $\mathrm{N}=$ north; $\mathrm{ESE}$ = east-southeast; SSW = southsouthwest; NE = northeast; NW = northwest; SE = southeast.

${ }^{2}$ Average yield is the forage production data averaged over $3 \mathrm{yr}$ for each site.

of the annual precipitation occurred during the growing season (April to September) and 61\% of growing season precipitation occurred during the spring (April to June). May and June had the greatest average monthly precipitation and also exhibited the greatest variation in precipitation, a fact which in itself suggests May and June precipitation would be important for predicting drought. The warmest maximum daily temperatures oc- curred in June, July, and August (Table 2). High temperatures and low precipitation in late summer coincided with summer dormancy.

Predicted and Simulated Yield Indexes. Using all available climatic data, the best prediction equation for simulated yield index included April and May precipitation, January and July average maximum temperature, and May minimum temperature $\left(\mathrm{R}^{2}=0.87\right.$, Table $3)$. Constraining predictor variables to those measured prior to July, the resulting equation included October and November from the prior calendar year, April and May precipitation, and April minimum temperature $\left(\mathrm{R}^{2}=0.89\right)$. The last step was to constrain variables to only precipitation prior to July because temperature explained very little of the variation in simulated yield index (Table 3 ). The final equation included previous October and November and April and May precipi-

Table 2. Average monthly precipitation, maximum and minimum temperatures for Miles City, MT

\begin{tabular}{|c|c|c|c|c|c|c|}
\hline Month & $\begin{array}{l}\text { Precipitation } \\
(\mathrm{cm})\end{array}$ & SD & $\begin{array}{c}\text { Maximum } \\
\text { temperature }\left({ }^{\circ} \mathrm{C}\right)\end{array}$ & SD & $\begin{array}{c}\text { Minimum } \\
\text { temperature }\left({ }^{\circ} \mathrm{C}\right)\end{array}$ & SD \\
\hline January & 1.05 & 1.07 & -0.82 & 6.05 & -13.75 & 5.03 \\
\hline March & 2.68 & 2.38 & 9.69 & 4.42 & -4.69 & 2.38 \\
\hline April & 3.54 & 3.18 & 16.97 & 3.94 & 1.22 & 1.76 \\
\hline May & 6.33 & 4.25 & 22.64 & 3.49 & 7.16 & 1.36 \\
\hline August & 3.25 & 2.66 & 28.49 & 3.54 & 14.89 & 1.89 \\
\hline September & 3.28 & 2.49 & 20.36 & 3.88 & 8.24 & 1.71 \\
\hline October & 2.67 & 3.33 & 12.28 & 5.03 & 1.72 & 1.32 \\
\hline November & 1.16 & 1.18 & 3.93 & 4.04 & -5.79 & 2.81 \\
\hline December & 1.34 & 0.91 & -1.07 & 4.50 & -11.69 & 4.02 \\
\hline Total & 35.22 & 11.12 & - & - & - & - \\
\hline
\end{tabular}


tation as predictors of simulated yield index $\left(\mathrm{R}^{2}=0.84\right)$.

It is interesting to note that all of the temperature variables, whether maximum or minimum, had negative coefficients, and all the precipitation variables had positive coefficients (Table 3 ). This implies that herbage production was enhanced by cool, wet weather. However, partial $\mathrm{R}^{2}$ values (Table 4 ) showed that precipitation variables explained a considerably greater amount of the variation than temperature variables.

There was a strong relationship between the simulated yield index from Rangetek and the predicted yield index from regression equation 3 from Table 3 (Figure 1). Trends were nearly identical, with magnitude of annual shifts in yield

\section{Table 3. Regression equations predicting simulated forage yield
index from precipitation and temperature data for Miles City, $\mathrm{MT}^{1}$ \\ Table 3. Regression equations predicting simulated forage yield
index from precipitation and temperature data for Miles City, $\mathrm{MT}^{1}$

\begin{tabular}{|c|c|c|c|}
\hline & Regression equations ${ }^{2,3}$ & $\mathbf{R}^{2}$ & $\mathrm{MSE}^{2}$ \\
\hline 1 & $\begin{array}{l}Y=1.348+0.037 \times(\text { April Precip })+0.018 \times(\text { May Precip })- \\
0.005 \times(\text { January Max Temp })-0.031 \times(\text { July Max Temp })- \\
0.034 \times(\text { May Min Temp })\end{array}$ & 0.87 & 0.155 \\
\hline 2 & $\begin{array}{l}Y=0.048+0.014 \times(\text { October Precip })+0.039 \times(\text { November } \\
\text { Precip })+0.041 \times(\text { April Precip })+0.023 \times(\text { May Precip })- \\
0.025 \times(\text { April Min Temp })\end{array}$ & 0.89 & 0.158 \\
\hline 3 & $\begin{array}{l}Y=0.008+0.015 \times(\text { October Precip })+0.044 \times(\text { November } \\
\text { Precip })+0.041 \times(\text { April Precip })+0.020 \times(\text { May Precip })\end{array}$ & 0.84 & 0.186 \\
\hline \multicolumn{4}{|c|}{${ }^{1} \mathrm{MS}$ error (MSE) units are squared index units. } \\
\hline \multicolumn{4}{|c|}{$\begin{array}{l}{ }^{2} \text { Precip = precipitation, Max Temp = maximum temperature, Min Temp = } \\
\text { minimum temperature. }\end{array}$} \\
\hline \multicolumn{4}{|c|}{$\begin{array}{l}{ }^{3} \text { Equation } 1 \text { was developed using all available climatic variables (precipitation, } \\
\text { maximum and minimum temperatures); Equation } 2 \text { was developed using all } \\
\text { variables prior to July; Equation } 3 \text { was developed using only precipitation } \\
\text { variables prior to July. }\end{array}$} \\
\hline
\end{tabular}

Table 4. Partial $R^{2}$ of variables for each regression equation predicting simulated forage yield index for Miles City, MT

\begin{tabular}{|c|c|c|c|}
\hline \multirow[b]{2}{*}{ Variable } & \multicolumn{3}{|c|}{ Partial $R^{2}$ for regression equations ${ }^{1}$} \\
\hline & 1 & 2 & 3 \\
\hline October precipitation & - & 0.06 & 0.08 \\
\hline November precipitation & - & 0.06 & 0.07 \\
\hline April precipitation & 0.39 & 0.39 & 0.39 \\
\hline May precipitation & 0.29 & 0.29 & 0.29 \\
\hline January maximum temperature & 0.03 & - & - \\
\hline July maximum temperature & 0.10 & - & - \\
\hline April minimum temperature & - & 0.08 & - \\
\hline May minimum temperature & 0.06 & - & - \\
\hline Total & 0.87 & 0.89 & 0.84 \\
\hline
\end{tabular}

${ }^{1}$ Equation 1 was developed using all available climatic variables (precipitation, maximum and minimum temperatures); Equation 2 was developed using all variables prior to July; Equation 3 was developed using only precipitation variables prior to July. 


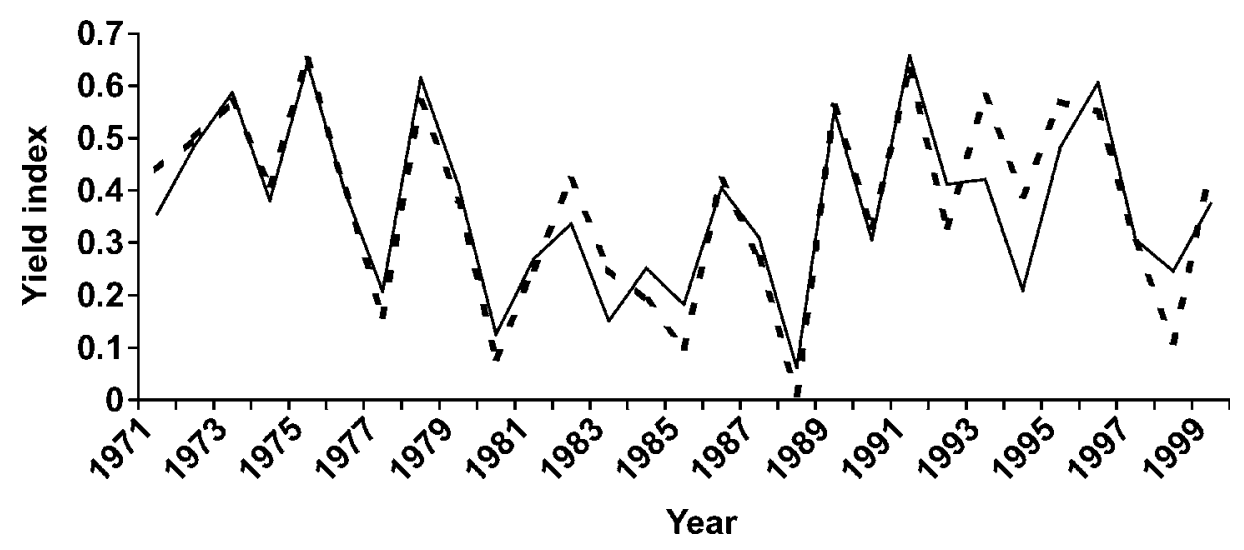

Figure 1. Simulated yield index output from Rangetek (dashed line) and the predicted yield index (solid line) using the regression model developed from monthly precipitation variables (Equation 3, Table 3) for Miles City, MT.

Miles City data, trends in annual shifts in yield indexes were similar, but magnitude of shifts was considerably greater for Rangetek simulations than regression predictions. This may be due to chance alone or some fundamental differences between locations. For example, the growing seasons at Lethbridge and Miles City are quite different, as below freezing average monthly temperatures prevailed in Lethbridge between October and April (Table 5) and in Miles City below freezing average monthly temperatures occurred only November through March (Table 2).

\section{Predicted and Actual Forage}

Yield. Using all available climatic data, the best regression equation predicting forage yield, as estimated from September harvests (Smoliak, 1986), included April, June, and July precipitation, plus April maximum temperature and November and June minimum temperature $\left(\mathrm{R}^{2}=0.71\right.$, Table 6$)$. Constraining predictors to those measured prior to July yielded an equation that included September, April, May, and June precipitation, January maximum temperature, and previous year's August minimum temperature $\left(\mathrm{R}^{2}=0.66\right)$. Us- ing only precipitation variables, the best equation included February, April, May, and June $\left(\mathrm{R}^{2}=\right.$ 0.56). February precipitation only explained $7 \%$ of the variation in actual forage yield (Table 7); however, its biological significance is suspect because such little precipitation is experienced during February and the soil would be frozen, presumably limiting precipitation's effect. When February precipitation was removed, and the resulting equation included April, May, and June $\left(\mathrm{R}^{2}=0.50\right)$.

As was found in Miles City, all of the temperature variables had negative coefficients (Table 6). This described the relationship between temperature and forage yield index to be negative and consistent between the 2 locations. Table 7 shows the partial $\mathrm{R}^{2}$ values, which were again consistent with Miles City; i.e., temperature variables explained only a small amount of variation. July precipitation did have a relatively high partial $\mathrm{R}^{2}$ value when predicting actual forage data, suggesting July precipitation is a key variable affecting forage production in Alberta.

Predicted annual forage production followed the same trends as actual production (Figure 3). But as with the simulated Rangetek yield

Table 5. Average monthly precipitation, maximum and minimum temperatures for Lethbridge, $A B$, Canada

\begin{tabular}{|c|c|c|c|c|c|c|}
\hline Months & $\begin{array}{l}\text { Precipitation } \\
\text { (cm) }\end{array}$ & SD & $\begin{array}{c}\text { Maximum } \\
\text { temperature }\left({ }^{\circ} \mathrm{C}\right)\end{array}$ & SD & $\begin{array}{c}\text { Minimum } \\
\text { temperature }\left({ }^{\circ} \mathrm{C}\right)\end{array}$ & SD \\
\hline January & 2.16 & 1.62 & -6.93 & 5.88 & -18.19 & 5.47 \\
\hline March & 2.20 & 1.64 & 1.55 & 4.03 & -9.88 & 3.28 \\
\hline April & 2.97 & 2.70 & 11.23 & 3.39 & -1.86 & 2.15 \\
\hline May & 4.12 & 2.91 & 18.14 & 2.29 & 4.29 & 1.36 \\
\hline August & 2.95 & 2.23 & 26.49 & 2.22 & 10.74 & 1.37 \\
\hline September & 2.47 & 2.02 & 20.11 & 2.75 & 5.15 & 1.70 \\
\hline October & 1.54 & 1.39 & 13.32 & 2.77 & -0.85 & 1.63 \\
\hline November & 1.54 & 1.28 & 3.50 & 3.77 & -8.58 & 2.98 \\
\hline December & 1.87 & 1.39 & -2.93 & 4.15 & -14.21 & 3.75 \\
\hline Total & 32.81 & 8.86 & - & - & - & - \\
\hline
\end{tabular}




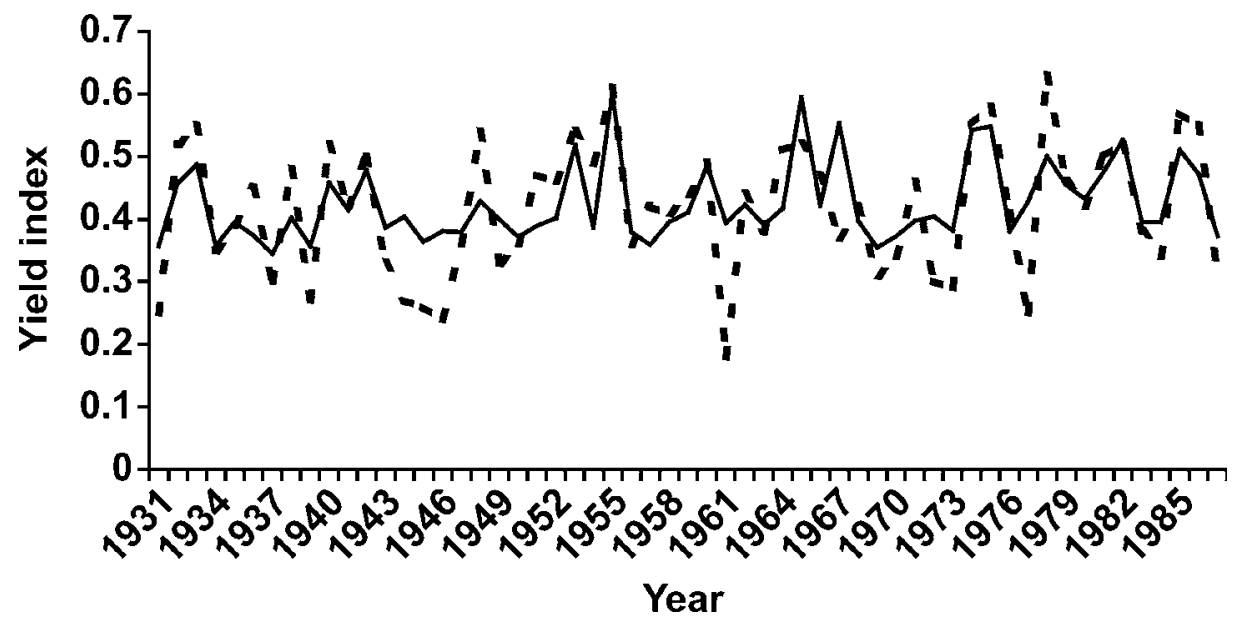

Figure 2. Simulated yield index output from Rangetek (dashed line) and the predicted yield index (solid line) using the regression model developed from monthly precipitation variables (see text) for Lethbridge, AB, Canada.

indexes (Figure 2), magnitude of annual shifts in production were not well predicted in some instances. Figure 4 compares annual Rangetek simulated yield index values to actual annual forage production. The correlation between simulated yield index and actual forage production was $0.59(P<0.01)$. Directional trends were similar among years, but annual variations tended to be greater for Rangetek simulated values than actual production. This may imply that Rangetek simulations were affected more by April and May precipitation and less by summer precipitation than actual production. This in turn suggests caution should be exercised when using Rangetek to predict forage production in Alberta. Still, analyses of both actual and simu- lated data sets revealed that spring and early summer precipitation were important determinants of level of annual forage production.

This project included analyses of both actual and simulated data. Simulated forage yield was used because we did not have a data set representing our immediate region (i.e., eastern Montana) that was sufficient to address our objectives. Actual historical data (Alberta) served to provide not only a second location, but also a check on the simulation approach. Prediction equations for forage production based on simulated or actual data yielded similar conclusions, providing evidence that our conclusions based on use of the Rangetek model in Miles City were reasonable.

Our approach was to develop practical early predictors of forage production as affected by emerging drought. Early prediction is prerequisite to providing livestock managers with the opportunity to make meaningful management changes that minimize the negative effects of drought on rangelands as well as beef enterprises (Kruse et al., 2007). Our results suggest that forage production can be predicted with

Table 6. Regression equations predicting actual forage yield from precipitation and temperature data for Lethbridge, $A B$, Canada

\begin{tabular}{|c|c|c|c|}
\hline & Regression equations $s^{1,2}$ & $\mathbf{R}^{2}$ & $\mathrm{MSE}^{3}$ \\
\hline 1 & $\begin{array}{l}Y=547.08+15.38 \times(\text { April Precip })+13.74 \times(\text { June Precip })+28.13 \times(\text { July Precip }) \\
-11.79 \times(\text { April Max Temp })-8.98 \times(\text { November Min Temp }) \\
-38.04 \times(\text { June Min Temp })\end{array}$ & 0.71 & 126,393 \\
\hline 2 & $\begin{array}{l}Y=378.85+19.89 \times(\text { September Precip })+22.91 \times(\text { April Precip }) \\
+18.14 \times(\text { May Precip })+16.77 \times(\text { June Precip }) \\
-7.00 \times(\text { January Max Temp })-32.83 \times(\text { August Min Temp })\end{array}$ & 0.66 & 117,055 \\
\hline 3 & $\begin{array}{l}Y=93.63+24.64 \times(\text { February Precip })+26.33 \times(\text { April Precip }) \\
+11.94 \times(\text { May Precip })+18.69 \times(\text { June Precip })\end{array}$ & 0.56 & 151,556 \\
\hline $3 b$ & $\begin{array}{l}Y=136.77+30.01 \times(\text { April Precip })+12.76 \times(\text { May Precip }) \\
+16.68 \times(\text { June Precip })\end{array}$ & 0.50 & 180,103 \\
\hline
\end{tabular}

${ }^{1}$ Precip = precipitation, Max Temp = maximum temperature, Min Temp = minimum temperature.

${ }^{2}$ Equation 1 was developed using all available climatic variables (precipitation, maximum and minimum temperatures); Equation 2 was developed using all variables prior to July; Equation 3 was developed using only precipitation variables prior to July; Equation 3b was developed the same as Equation 3, but removing February from possible variables.

${ }^{3} \mathrm{MS}$ error (MSE) units are $(\mathrm{kg} / \mathrm{ha})^{2}$. 
Table 7. Partial $R^{2}$ of variables for each regression equation predicting actual forage yield for Lethbridge, $A B$, Canada

\begin{tabular}{lcccc} 
& \multicolumn{4}{c}{ Partial $\mathrm{R}^{2}$ for regression equations ${ }^{1}$} \\
\cline { 2 - 5 } Variable & 1 & 2 & 3 & $3 \mathrm{~b}$ \\
\hline September precipitation & - & 0.06 & - & - \\
February precipitation & - & - & 0.07 & - \\
April precipitation & 0.28 & 0.28 & 0.28 & 0.28 \\
May precipitation & - & 0.05 & 0.05 & 0.05 \\
June precipitation & 0.17 & 0.17 & 0.17 & 0.17 \\
July precipitation & 0.15 & - & - & - \\
January maximum temperature & - & 0.04 & - & - \\
April maximum temperature & 0.03 & - & - & - \\
August minimum temperature & - & 0.06 & - & - \\
November minimum temperature & 0.03 & - & - & - \\
June minimum temperature & 0.06 & - & - & - \\
Total & 0.71 & 0.66 & 0.56 & 0.50
\end{tabular}

${ }^{1}$ Equation 1 was developed using all available climatic variables (precipitation, maximum and minimum temperatures); Equation 2 was developed using all variables prior to July; Equation 3 was developed using only precipitation variables prior to July; Equation $3 \mathrm{~b}$ was developed the same as Equation 3, but removing February from possible variables. some confidence from spring (April through June) precipitation at both Miles City, MT, and Lethbridge, Alberta. Although temperature and July precipitation added reliability to the models statistically, they added complexity and decreased the utility of the models as early, practical predictors of forthcoming forage conditions. Temperature and July precipitation variables increased the ability of the regression equations to explain the variation seen in forage production, but the proportion of the variation explained by each variable was small and inconsistent. To us it appears less practical for producers to col-

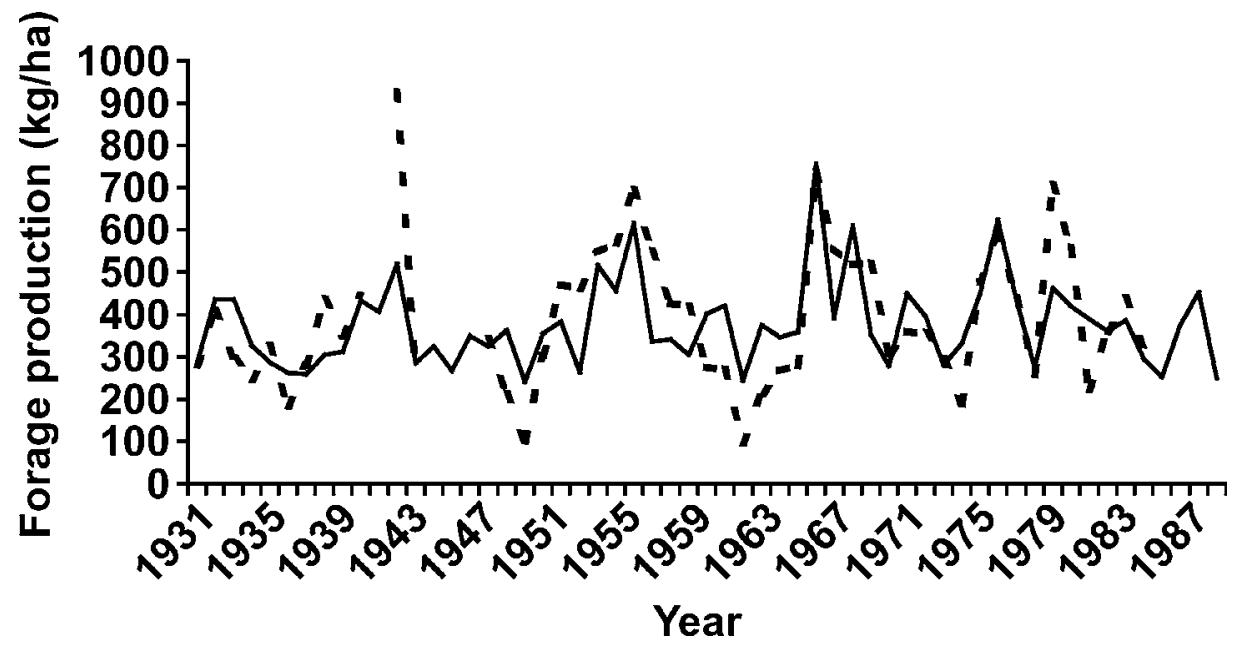

Figure 3. Actual forage production (dashed line) vs. predicted forage production (solid line, Equation 3b, Table 6) forage production data for Lethbridge, AB, Canada. lect average temperature measurements; many ranchers keep track of precipitation.

The majority of the research reported in the last $70 \mathrm{yr}$ has shown that some measure of precipitation is one of the most important factors in forage growth (see review by Kruse, 2002). Sneva and Hyder (1962a,b) performed similar work utilizing yield indices and found that semiarid communities of native or well-adapted introduced species fluctuated with precipitation in a fairly uniform and predictable manner when data were collated during a growing season. Wight et al. (1984) used the Rangetek model to relate soil water and climatic parameters to plant growth. They found that two-thirds of the fieldmeasured yields were within one SD of forecasted yields for the April, May, and June forecasts using $55 \mathrm{yr}$ of weather records and 12 $\mathrm{yr}$ of actual yield and soil water data. Hanson et al. (1982) compared long-term historical and stochastically generated weather records in terms of their statistical attributes and effects on herbage yield and runoff forecasts calculated from the Rangetek model simulations. Yield forecasts were similar using either historical or synthetic weather records.

Our results suggest that predictions based on spring precipitation could be used effectively to make management decisions as early as July 1. Sneva and Hyder (1962a,b) in eastern Oregon and Smoliak (1956) in Southern Alberta declared that predictions of forage production could be utilized by July 1 as well. Although Smoliak (1986) conceded, as we do, that August 1 is a more reliable date than July 1 for predicting drought, we advocate July 1 because 1) it has been shown that on average $91 \%$ of perennial grass forage production is completed by July 1 at Fort Keogh Laboratory (Heitschmidt and Vermeire, 2005); and 2) July 1 provides one additional month of time 


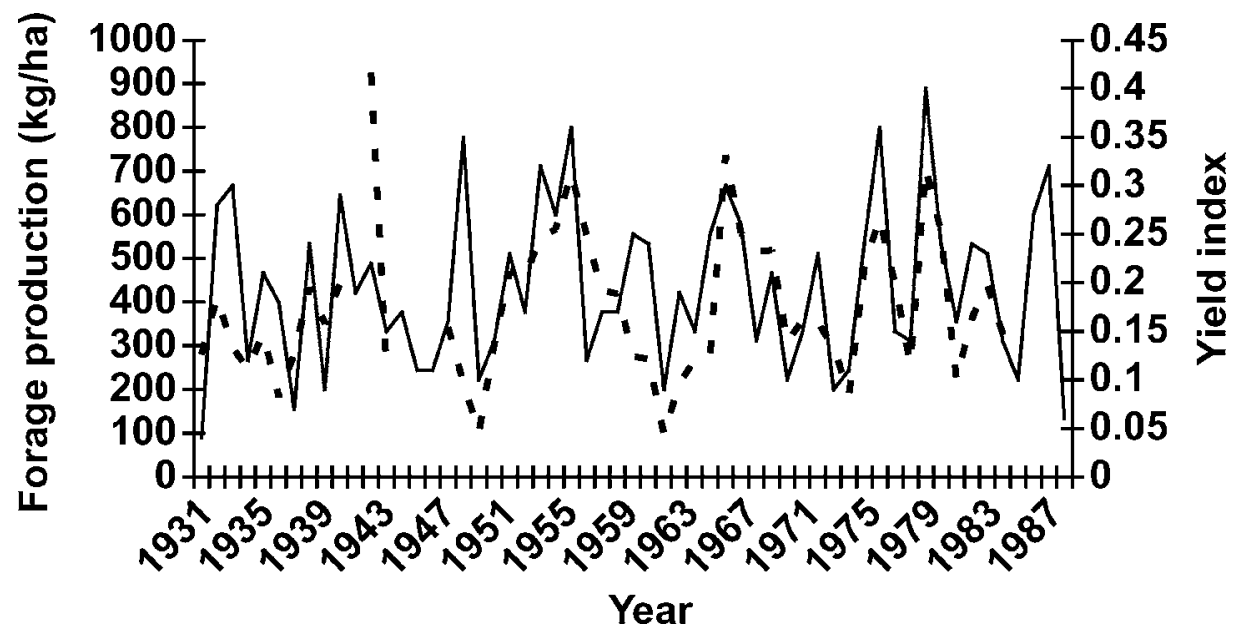

Figure 4. Simulated yield index values from Rangetek (solid line) vs. actual forage production data (dashed line) for 50 yr for Lethbridge, AB, Canada.

to respond to drought. Still, responding to drought in August is certainly better than failing to respond at all.

It has been shown that use of prediction equations should be limited to areas of similar vegetation and soil type (Cannon and Nielson, 1984). Differences in equations developed for Fort Keogh Laboratory and Manyberries Substation appear to support this concept. However, for the specific purpose of early prediction of drought, all the models define spring and early summer as predictors of forage production.

\section{IMPLICATIONS}

Ranchers can use weather records to reasonably forecast forage production by July 1 . Practically, forage produced by early July is a good indicator of growing season forage production. Producers can then detect drought-reduced forage production and change management strategies early in the growing season to forestall some of the negative impacts of drought on range resources and livestock performance.

\section{ACKNOWLEDGMENTS}

The authors gratefully acknowledge the Agriculture and Agri-Food Canada Manyberries Substation for graciously sharing data used in partial completion of this project.

\section{LITERATURE CITED}

Albertson, F. W., G. W. Tomanek, and A. Riegel. 1957. Ecology of drought cycles and grazing intensities on grassland of the Central Great Plains. Ecol. Monogr. 27:27.

Cannon, M. E., and G. A. Nielson. 1984. Estimating production of range vegetation from easily measured soil characteristics. Soil Sci. Soc. Am. J. 48:1393.

Ellison, L., and E. J. Woolfolk. 1937. Effects of drought on vegetation near Miles City, Montana. Ecology 18:329.

Hanson, C. L., J. R. Wight, J. P. Smith, and S. Smoliak. 1982. Use of historical yield data to forecast range herbage production. J. Range Manage. 35:614.

Heitschmidt, R. K., M. R. Haferkamp, M. G. Karl, and A. L. Hild. 1999. Drought and grazing: Effects on quantity of forage produced. J. Range Manage. 52:440.

Heitschmidt, R. K., and L. T. Vermeire. 2005. An ecological and economic risk avoidance drought management decision support system. In: Pastoral Systems in Marginal Environments. J. A. Milne, ed. p. 178. Proc. Satellite Workshop, XX Int.Grassland Congr., Glasgow, Scotland. Wageningen Academic Publ. Wageningen, The Netherlands.
Heitschmidt, R. K., and L. T. Vermeire. 2006. Can abundant summer precipitation counter losses in herbage production caused by spring drought? J. Range. Ecol. Manage. 59:392.

Herbel, C. H., J. D. Wallace, M. D. Finkner, and C. C. Yarbrough. 1984. Early weaning and part-year confinement of cattle on arid rangelands of the southwest. J. Range Manage. 37:127.

Hurtt, L. C. 1951. Managing Northern Great Plains cattle ranges to minimize the effects of drought. USDA Cir. No. 865.

Jensen, M. E., and H. R. Haise. 1963. Estimating evapotranspiration from solar radiation. Amer. Soc. Civil Eng. Proc. J. Irrig. Drain. Div. 89:15.

Johnson, C. A. 1985. Simulated effects of supplementary water on two grasslands, Agropyron smithii and Bouteloua gracilis. M.S. Thesis, Montana State University, Bozeman.

Kruse, R. E. 2002. Beef cattle management decisions relating to drought in the Northern Great Plains. M.S. Thesis, Montana State University, Bozeman.

Kruse, R. E., M. W. Tess, and R. K. Heitschmidt. 2007. Livestock management during drought in the Northern Great Plains. II. Evaluation of alternative strategies for cowcalf enterprises. Prof. Anim. Sci. 23:234.

Kuchler, A. 1964. Potential natural vegetation of the coterminous United States. Special Publication 36. Am. Geogr. Soc., New York, NY.

Kulshreshtha, S. N. 1989. Agricultural drought impact evaluation model: A systems approach. Agric. Syst. 30:81.

NOAA. 2001. National Oceanic and Atmospheric Administration. U.S. Department of Commerce. http://www.noaa.gov/index.html Accessed Nov. 1, 2001.

Smoliak, S. 1956. Influence of climatic conditions on forage production of shortgrass rangeland. J. Range Manage. 9:89.

Smoliak, S. 1986. Influence of climatic conditions on production of Stipa-Bouteloua prairie over a 50- year period. J. Range Manage. 39:100.

Sneva, F. A., and D. N. Hyder. 1962a. Estimating herbage production on semiarid ranges in the intermountain region. J. Range Manage. 15:88.

Sneva, F. A., and D. N. Hyder. 1962b. Forecasting range herbage production in eastern Oregon. Oregon Exp. St. Bull. No. 588.

Thurow, T. L., and C. A. Taylor. 1999. Viewpoint: The role of drought in range management. J. Range Manage. 52:413.

Valentine, J. F. 1990. Grazing Management. Academic Press, Inc., San Diego, CA.

Weaver, J. E., and F. W. Albertson. 1936. Effects of the great drought on the prairies of Iowa, Nebraska, and Kansas. Ecology 17:567. 
Weaver, J. E., and F. W. Albertson. 1939. Major changes in grassland as a result of continued drought. Bot. Gaz. 100:576.

Weaver, J. E., and F. W. Albertson. 1944. Nature and degree of recovery of grassland from the great drought of 1933 - 1940. Ecol. Monogr. 14:393.

Weltzin, J. F., and G. R. McPherson. 2003. Changing Precipitation Regimes and Terrestrial Ecosystems: A North American Perspective. Univ. Arizona Press, Tucson.
Whitman, W., H. C. Hanson, and R. A. Peterson. 1943. Relation of drought and grazing to North Dakota rangelands. North Dakota Agric. Exp. St. Bull. 320.

Wight, J. R. 1987. ERHYM-II: Model description and user guide for the BASIC version. USDA, ARS 59, Beltsville, MD.

Wight, J. R., and R. J. Hanks. 1981. A water-balance, climate model for range herbage production. J. Range Manage. 34:307.
Wight, J. R., C. L. Hanson, and D. Whitmer. 1984. Using weather records with a forage production model to forecast range forage production. J. Range Manage. $37: 3$

Wight, J. R., and E. L. Neff. 1983. Soil-vegetation-hydrology studies Vol. II. A User Manual for ERHYM: The Ekalaka Rangeland Hydrology and Yield Model. USDA-ARS. ARR-W-29, Oakland, CA. 